\title{
Big picture wisdom: Metatheorising ancient, scientific and indigenous wisdom perspectives for global environmental leadership
}

\author{
Mark Edwards \\ University of Western Australia \\ Roberto Biloslavo \\ University of Primorska, Slovenia \\ Blaze Kwaymullina \\ Terra Rosa, Cultural Resource Management \\ Ambelin Kwaymullina \\ University of Western Australia
}

\begin{abstract}
In response to growing global environmental crises and drawing on new ideas from theorybuilding literature, we seek to develop a radical re-conceptualisation of wise leadership. Communities across the world are facing global challenges which have profound implications for the long-term viability and welfare of natural environments and human social and economic systems. "Big picture" wisdom, that is, a social practice wisdom that can address global environmental challenges, is called for. A metatheoretical review of ancient, scientific and Indigenous conceptualisations of wisdom identifies conceptual lenses that have application to global environmental leadership. Lenses identified as essential for this development include intergenerational time frame, radical relationality, multi-level ecology and integrated sacredness. Integrating conventional scientific and Indigenous views creates the potential for a more expansive and yet grounded means for conceptualising what it means to lead wisely.
\end{abstract}

Keywords: wisdom, wise leadership, Indigenous knowledge, global environmental crises, metatheoretical lens

\section{INTRODUCTION}

Environmental problems often originate from a too narrow scope in the fragmented fields of science, politics, administration, education, etc. If only a narrow view is adopted, the measures taken in order to solve the problems are probably too narrow as well.

(Tapio \& Willamo, 2008, p. 130)

Any insights from Indigenous wisdom in regard to ecosystems are of huge potential interest, given that modern society has not been particularly successful in managing ecosystems sustainably.

(Berkes \& Berkes, 2009, p. 6)

In this paper we draw together ancient, scientific and Indigenous views of wisdom and discuss how they can add to our understandings of global environmental leadership. Theories of leadership have emphasised its multilevel nature and application for many years (Graen \& Uhl-Bien, 1995; Hernandez, Eberly, Avolio, \& Johnson, 2011; Yammarino, Dionne, Schriesheim, \& Dansereau, 2008) and notions of environmental

Correspondence concerning this article should be addressed to Assist. Prof. Mark Edwards, Business School, The University of Western Australia, 35 Stirling Highway, Crawley, WA 6009. email:

mark.edwards@uwa.edu.au 
leadership and green management have been in existence for over two decades (Portugal \& Yukl, 1994; Taylor, 1992). This period has also seen the emergence of the scientific study of wisdom and the development of theories of wise leadership (Yang, 2011), authentic leadership (Avolio, Walumbwa, \& Joseph, 2006) and forms of leadership that require exceptional levels of knowledge, ethical competence and practical expertise (Voegtlin, Patzer, \& Scherer, 2012).

These diverse fields of study possess great potential for cross-fertilisation. We look across these domains and ask, how might wisdom research contribute to understandings of leadership that are adequate for dealing with global environmental crises? Drawing on recent ideas from the theory-building literature (Oswick, Fleming, \& Hanlon, 2011) we look to an unusual and underutilised cultural source for building new perspectives on wisdom and wise leadership, namely, systems of Indigenous knowledge systems and, in particular, those from Australian Indigenous culture.

Indigenous peoples across the planet have survived and flourished through many periods of social, cultural and environmental change. Australian Indigenous cultures have, for example, been dealing with issues of sustainability and environmental transformation for many tens of thousands of years (Taylor, 2005). It has been known for several decades that the first Australians possessed sophisticated and powerful technologies which they used to manage and alter natural environments of all kinds (Jones, 1969). Although their activities impacted across the entire continent, Indigenous peoples of Australia achieved and sustained rich and diverse cultures and natural environments for immensely long time periods (Gammage, 2011). This intergenerational sustainability, and the knowledge and wisdom that produced it, are common features of many other Indigenous societies across the world (Spiller, Pio, Erakovic, \& Henare, 2011). However, the scientific study of wisdom has left this source of knowledge largely unexplored. At the same time, leadership researchers have proposed the notion of "global leadership" and the need for the "meta-values" (De Vries \& Flornet-Traecy, 2002) and "meta-competencies" (Tubbs \& Schulz, 2006) in dealing with complex global problems. Building "big picture" or metatheoretical conceptualisations of leadership must also include indigenous views to be truly global. Zhang and colleagues (Zhang et al., 2012, p. 1063) have stated that:

As the business world becomes increasingly globalized, the need to understand leadership across the world is also becoming more and more urgent, making indigenous research increasingly important and necessary.

In response to this call we bring together Indigenous and scientific traditions of wisdom research with the aim of building Big Picture environmental leadership, one that is requisite to the global crises we currently face.

The paper is structured as follows. We first review perspectives on wise leadership and the natural environment from philosophical, scientific and Indigenous perspectives. From this review we identify key conceptual lenses for the development of a Big Picture approach to wise leadership. Such a theory of wise leadership will need to integrate abstract concepts which concern the natural world as well as the social and psychological. We hope to draw attention to the dimension of wisdom that is sensitive to global environmental sustainability and personal and communal wellbeing. In this theory-building task we are guided by Oswick, Fleming and Hanlon and their concept of "radical travelling theory" (Oswick et al., 2011, p. 322). We import broad ideas with a high level of abstraction from radically diverse disciplines. As Oswick and colleagues say:

It is precisely because radical theories are broad, "foreign" (in the sense of being alien and not management focused), and highly abstract that they are perceived to have purchase as fresh, appealing, and seductive ways of exploring organizational phenomena. ... In the case of radical travelling theory, this means that these [foreign] theories are imported by organizational scholars and, to an extent, deradicalized in order to be more narrowly applied to organizational phenomena and subareas of inquiry. (Oswick et al., 2011, p. 323)

We import theories of wisdom and wise leadership ideas from a radically divergent area - the Indigenous wisdom traditions. The metatheoretical analysis of such diverse positions opens up integrative possibilities and, in this analysis section, we compare core dimensions to identify divergent and convergent understandings between the different perspectives. Some examples of big picture wisdom and how it contributes to sustainability research will be presented. This application section will be guided by the "loci and mechanisms" model (Hernandez et al., 2011) which outlines a comprehensive framework for codifying leadership theories and their application (see Figure 1). Finally, we explore some general implications of the metatheory for the study of wisdom, and organisation and management studies in sustainability. 


\section{INTEGRATIVE THEORY BUILDING}

Our method in this metatheory-building endeavour will be based on the integrative review approach (Lynham, 2000; Torraco, 2005; Whittemore \& Knafl, 2005). Theory and metatheory building, that is, the review of existing conceptual systems to construct new theory, can be contrasted with the more common forms of research that focus on theory testing, where existing theory is applied and tested on empirical grounds. One of the chief means for building new theories and metatheories is via the integrative review of extant frameworks so that new explanatory lenses can be identified and developed. The phases in this method are (see Figure 1): i) to introduce the topic and describe the background and purpose of the integrative review, ii) theory review and development, where extant perspectives are reviewed and extended to develop new theory, iii) theory description, where the new framework and its elements are described, and iv) theory application, where the potential areas for applying the new approach and/or new insights are explored.

\section{Figure 1: Review, development, description and application of Big Picture Wisdom}

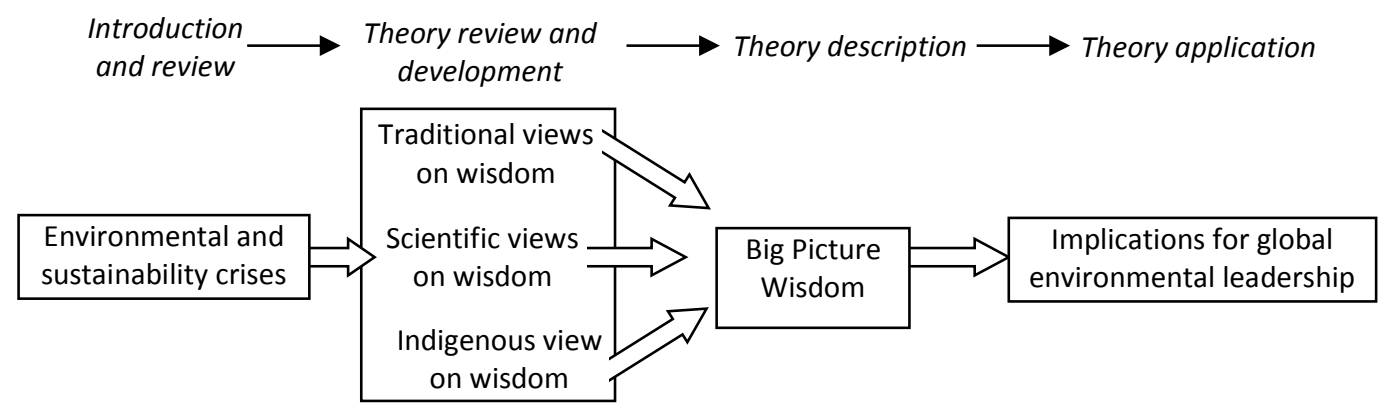

In presenting a very basic overview of ancient, contemporary scientific and Indigenous theories and perspectives on wisdom we will draw on secondary literature. The vast literature on this topic does not permit a detailed review here of each of these domains.

\section{WISDOM, LEADERSHIP AND GLOBAL CRISES}

Communities, institutions and businesses are facing many global challenges that have implications for the long-term viability and welfare of natural environments and human communities (Hajkowicz, Cook, \& Littleboy, 2012). The implications and repercussions of these global issues are impacting directly on every level and sphere of ecological and social activity. The chairman of the World Economic Forum (WEF), Claus Schwab, recently stated that in the coming decades "our lives will be more intensely shaped by transformative forces, including economic, environmental, geopolitical, societal and technological seismic shifts" (WEF, 2012, p. 8). He sees the complexities arising from environmental changes as threatening to "overwhelm countries, companies, cultures and communities" (WEF, 2012, p. 8).

Whether they are environmental, social or economic in origin, these challenges will require transformative changes in the mindsets and actions of individual leaders and in the cultures and practices of their organisations. Transformation on the scale required for real change will demand an unprecedented display of visionary leadership and ethical commitment (Maak \& Pless, 2006). A new sense of global connectedness and sensitivity for the long-term impact of human activities is required to effectively respond to these challenges.

The latest version of the WEF's "Global Risks" report asks the question, "The economic and environmental challenges [facing the world] require both structural changes and strategic investments, but are countries prepared to manage both fronts, conceivably at the same time?" (World Economic Forum, 2013). Dealing with multiple crises on multiple fronts requires exceptional levels of leadership. Wise decisions, wise planning and wise actions are called for to navigate the complexities thrown up by global challenges. Referring to this nexus between leadership, wisdom and global crises, Yang (2011, p. 616) states:

Examining wisdom displayed through leadership can shed light on the discussion of leadership and refocus our attention from increasing profits to promoting the common good. Difficult problems, such as global warming and financial crises, may be resolved or avoided if leadership is executed with wisdom. 
The presence or absence of wise leadership is recognised most clearly during times of radical change where the risks are high and the potential for new possibilities and benefits contend with the chance of failure and loss. This is the situation in which organisations and the international business community find themselves today. Globalisation, technological advances and the expansion of international trade have brought significant economic benefits for many millions of people across the globe. But these rapid developments have also ushered in an era of social and environmental risks of unprecedented scale (Gup, 2010; World Economic Forum, 2013; WWF, 2012). Traditional ways of managing the ensuing complexities and risks and relying on market-led responses may not be adequate for addressing the kinds and scale of problems facing contemporary leaders. New forms of "transformative learning and transformative leadership" (O'Brien, 2012, p. 671) will be needed to facilitate the scale of requisite change.

An adaptive and integrated form of leadership in and by organisations is called for so that "new wisdom as well as new knowledge" (Thompson, 2010, p. 28) can be developed and practically utilised. Wise leaders at all levels of community and organisational life will become ever more crucial for organisational and global development in this time of global challenge. Quoting Boal, we are at a "strategic inflection point" where "absorptive capacity, capacity to change, and managerial wisdom" are needed (Boal, 2000, p. 520). Strategic inflection points are critical times when leaders call on diverse sources of knowledge and experience so that discerning and timely judgements, that is, wise judgements, can be made.

The diversity of qualities required for wise leadership will mean that it is not only a quality of individuals but also of collectives and of community engagement in taking and inspiring action. The complex matrix of qualities needed to be wise means that it will also be a characteristic that is shared and distributed across multiple levels in communities and organisations. Consequently, we adopt the view that "change leadership" is best viewed "as a cascading process that involves chains of interlocking role constellations at different levels" (Denis, Lamothe, \& Langley, 2001, p. 835).

\section{VIEWS OF WISDOM AND THEIR RELATION TO THE NATURAL ENVIRONMENT}

Wisdom and wise leadership have been the subjects of study and commentary since ancient times. Understanding contemporary scientific views and how they relate to natural environments are best explored within the broad context of wisdom literature. There is a very substantial body of literature on the wisdom traditions of the ancient Middle East, from the Greek philosophers, from Islamic cultures and from medieval and Renaissance periods. We do not intend in this article to review all this literature. What is of primary interest here is the fundamental perspectives and lenses with which the concept of wisdom and its relationship with the natural environment has been construed within these very different traditions, and particularly so between Western (ancient and modern) and Indigenous perspectives. Consequently, the following integrative review draws mostly on previous literature reviews to gain an understanding of the definitive aspects of wisdom across these different sources. The diversity of views does not mean that general themes cannot be evinced. Discussing the literature of Mesopotamia, Beaulieu says:

Wisdom literature is such a vast and inclusive notion that scholars have always experienced great difficulties in clearly defining its boundaries. Indeed, it is largely an intuitive category, based on a general recognition of certain themes and questions that wisdom literature is expected to address. (Beaulieu, 2007, p. 3)

Despite the immense diversity, it is these "certain themes and questions" and some common characteristics that authors have identified among these literatures that is our focus here.

\section{Ancient views on wisdom}

Attempts to describe the qualities of wise people, wise decisions and wise acts can be found in both oral traditions and written texts across many different cultures. Dating back as far as the second millennium BCE, references to wisdom can be found in Mesopotamian, Egyptian and Hebraic texts, in the sacred writings of Taoism, Zoroastrianism, Judaism, Confucianism and Buddhism. Detailed discussion on wisdom can be found in the works of the Greco-Roman philosophers and in scriptures, stories and theological writings of the JudaeoChristian and Islamic traditions. In several of the Middle Eastern cultures, the discussion of wisdom forms such an important and substantial body of work that it is referred to as "the wisdom writings" or "the wisdom literature" (Penchansky, 2012). In this very brief overview of ancient wirings, we focus on understandings of wisdom as they refer to the relationship between people and their natural surroundings. 
The variety of approaches in ancient texts to describing wisdom and the qualities of wise people is extensive (Perdue, 2007). However, as a distinct genre of writings and instruction, wisdom texts held a shared interest in what it meant to live a harmonious and successful life. "The general tenor of wisdom texts is to teach the art of leading a successful life, in harmony with society and the divine will" (Beaulieu, 2007). Different societies and ways of life gave rise to different understandings of what wisdom meant and these underwent changes as societies themselves developed. In Mesopotamian texts wisdom was concerned with pragmatic knowledge and planning, with being prudent and careful about the future, and with the faithful adherence to religious rules and divinely inspired regulation of behaviours and social customs.

Early Hebraic descriptions of wisdom were laid out as rules and advice for surviving in often harsh natural environments; to be wise had a decidedly practical bent (Waltke, 1979). The Book of Proverbs from the Hebrew Bible is a compendium of such instructions. But the Hebraic wisdom literature includes other wisdom writings which emphasise the intimate relationship between people and their God and so talk of wisdom becomes imbued with an ethical dimension (Perdue, 2007). Rooney, McKenna and Liesch point out that, in the Hebrew Bible, "wisdom is a suite of culture, moral virtues, intellectual qualities, and metaphysics whose source and inspiration rest in God" (Rooney, McKenna, \& Liesch, 2010, p. 19). Wisdom is concerned with practical knowledge but also moral rules and social expectations and an awareness of the personal and communal implications of flouting those rules.

In early texts, the natural environment was seen as a medium through which God punished or rewarded people for their actions and their obedience to the moral codes that guided behaviour. The early relationship between wisdom and the natural environment was of the struggle for control and mastery. To be wise was to have humility before the gods and the vagaries of weather and natural occurrences but also to plan, to manage and to astutely control what was within one's power to control. For example, there are many rules concerning storage of grain and putting aside resources for poorer times. The early wisdom writings included instructions on farming and with prospering in an agricultural context. Later texts focused more on cultural knowledge, personal virtue and leadership status.

In their review of Hebraic views on wisdom, Rooney, McKenna and Liesch (2010) propose that the notion of wisdom had four defining features: i) an essential quality of true leadership, ii) a kind of righteousness in the sense of a transparent compliance with Jewish religious law, iii) a transcendent aspect associated with divine transcendence, and iv) humility, discipline and forbearance, particularly during times of adversity. The association of wisdom with leadership emerged at the same time as the need for control over nature gained importance in both agricultural and trading contexts. The wise leader was someone who could advise on the right course of action, on the planning required to ensure prosperity for urban communities.

Wisdom was also a fundamental theme of discussion in the Greco-Roman schools of philosophy and, of course, the term philosophy is itself derived from the Greek "the love of wisdom". For the ancient Greeks, however, wisdom was associated with rational pursuits and the quest for knowledge. "Wisdom did not refer to precepts for living but, rather, to an investigation into the laws and constituents of the natural world" (Birren \& Svensson, 1990, p. 5). Where the Hebraic concept of wisdom is most often discussed in a religious context, the Hellenistic notions of wisdom emphasised human virtue in a temporal world (Rooney et al., 2010). For example, for Aristotle, wisdom is concerned with the development of character and is "necessarily a consolation that also includes character, integrity and ethics" (Rooney et al., 2010, p. 23). Aristotle's wisdom also seeks to be practical and worldly, is about social proficiency, good governance and about the qualities needed to govern the new society of a democratic city state. Hence it is wisdom as a social practice that distinguishes the Aristotlean from the Judaeo-Christian view.

The Judeo-Christian focus on wisdom as transcendence, otherworldliness and contemplative unity with the divine was continued for many centuries and exemplified in the monastic traditions that dominated European and Byzantine Christianity. With the rediscovery of the Greek philosophers and the interest in Islamic scholarship in the late medieval period however, wisdom once again became associated with practical insight into human affairs. The emergence of humanism during the Renaissance period saw a renewed interest in wisdom as an expression of human excellence, achievement and practical expertise (Robinson, 1990) in the arts, humanities and sciences. At this point in European history, we can distinguish two clear pathways by which wisdom was studied. One, the mystical stream, maintained the transcendental and contemplative wisdom tradition of the early Christian church. Works on wisdom from this lineage came from the saints, mystics and contemplatives that populated European monastic and religious lay communities (Feiss, 2000). The other stream took the more practical and humanistic line of Aristotle and Da Vinci and delved into the 
development of applied knowledge and education through the pursuit of the arts and sciences and their application to human endeavours.

Occasionally, within these streams there were figures who place the natural environment at the forefront of their insights and spiritual perspective. Notable individuals like Hildegard of Bingen (from the transcendent stream) and Leonardo da Vinci (from the humanist stream) did place nature at the centre of their spirituality and philosophy. However, such extraordinary individuals were the exception and neither of these wisdom streams, not the transcendent stream of experience and mystical knowledge nor the humanist stream of artistic, political and social improvement, had much to say about the natural world or with humanity's impact or use of it. The humanism of the Renaissance would eventually lead to the emergence of Romanticism in Europe that definitely did immerse itself in the natural world. However, by this time, talk of wisdom had long been sequestered into the activities of monasteries and in the academic study of philosophy.

Despite the great diversity of representations through the ancient Middle Eastern, Hellenistic, European medieval and Renaissance period, it is possible to discern some broad developments in how perspectives on wisdom and its relationship with the natural environment changed through these times (see Table 1 following). The very earliest sacred texts depicted wisdom as knowledge about pragmatic survival, military leadership and of the importance of appeasing the gods and nature though ritual and sacrifice. Knowledge of surviving nature's vicissitudes developed further into a moral sense and into following codes of behaviour that aligned individual with cultural norms. Wise leaders received and defended these codes and covenants. To be wise was not only knowing about material survival and military success but about modelling and upholding moral precepts. Wise leaders mediated between the divine and the human.

With the Greeks, wisdom moved further away from direct connection with nature and focused more on cultural and ethical concerns, existential dilemmas and the first glimmers of scientific knowledge. Wise leaders were those who wielded political power for the common good. The environment was, at best, a passive background in conceptualisations of wisdom and wise leadership. Wise political leadership was also a theme in medieval and Renaissance conception of wisdom but this soon merged into the humanist interest in political, cultural and artistic capacity. Overt discussion of wisdom became restricted to the monastic and religious notions of wisdom as transpersonal experience of the divine. At this point the tenuous connections that had existed between wisdom and environmental sensibilities became negligible and even antagonistic. The natural world was often characterised as something that needed to be transcended for wisdom to be acquired.

\section{Contemporary scientific views}

With the European enlightenment and the rise of Western science, the study of wisdom literally disappeared. In a chapter entitled "Where did talk of wisdom go?", Rooney, McKenna and Liesch discuss how wisdom became a "marginalised concept" in Western culture (Rooney et al., 2010, p. 18). The objectification of nature that occurred in the $18^{\text {th }}$ and $19^{\text {th }}$ centuries saw the dominance of analytical forms of science and the identification of exceptional human qualities to expert and specialist knowledge. It was only with the emergence of developmental psychology as a scientific discipline in the twentieth century that the scientific study of wisdom started in earnest (Hall, 2010). The most prominent contemporary scholars and theoretical schools of wisdom research are Robert Sternberg in the USA, the Berlin wisdom paradigm, the practical wisdom (phronesis) paradigm which has taken up Aristotlean understandings of wisdom work and, finally the empirical research school which is dominated by psychometric and neurobiological approaches. In summarising this extensive body of scientific literature we are guided by the work of previous reviewers (Ardelt, 2004; Meeks \& Jeste, 2009; Rooney et al., 2010) and will focus in particular on the place of the natural environment in the way these schools conceptualised wisdom.

\section{Robert Sternberg}

Sternberg has developed an elaborate notion of wisdom (Sternberg, 1998; 2003; Sternberg \& Jordan, 2005) that includes the exercise of successful intelligence and creativity, the interplay of values, a dynamic balance between intrapersonal, interpersonal and extrapersonal interests and a sensibility for the role of temporality in judging the outcomes of decisions. Wisdom, according to Sternberg, enables people to maintain a balance between adjusting existing environments, shaping changes to those environments, and choosing new environments (Sternberg, 2003). Wisdom is not about personal interests but a balancing out of different personal interests (intrapersonal aspect) with the interests of other people (interpersonal aspect) and with other aspects of the environment (extrapersonal aspect) (Sternberg, 1998). 
Although the term "environment" is frequently used in Sternberg's work, it refers to human interpersonal environments, organisational environments, task environments and never to natural environments. This is generally representative of most scientific research on wisdom where the focus has been on personal psychological and collective sociological functioning and the variety of socio-cultural environments in which these foci are situated. In Sternberg's WICS (Wisdom, Intelligence, Creativity, Synthesis) model of wise leadership, multiple forms of intelligence and creativity are synthesised within an overarching framework. None of these involve forms of intelligence or creativity that are concerned with natural environments or applications of intelligence and creativity to the natural world.

\section{The Berlin School}

The "Berlin wisdom paradigm" (Baltes \& Staudinger, 2000) is based on the research of Paul Baltes, Ursula Staudinger and others at the Max Planck Institute on Human Development in Berlin. The Berlin school defines wisdom as "expert knowledge in the fundamental pragmatics of life that permits exceptional insight, judgement, and advice about complex and uncertain matters" (Pasupathi, Staudinger, \& Baltes, 2001, p. 351). More specifically, these pragmatics include "insight into the social nature and incompleteness of human existence, the variability of life goals, knowledge about oneself and the limits of one's knowledge, and insight into how knowledge is translated into behaviour" (Staudinger \& Pasupathi, 2003, p. 240).

Unlike the Sternberg approach, the Berlin school sees wisdom as also expressed in collectives as objective social constructions embodied within legal and educational systems, contemplative institutions, art and books. Baltes, Gluck and Kunzmann proposed, for example, that "In general, wisdom is foremost a cultural product deposited in books of wisdom rather than in individuals" (Baltes, Glück, \& Kunzmann, 2002, p. 331). Thus, wisdom in both its individual and collective forms is closely linked to knowledge. For this reason the Berlin paradigm has been categorised as a cognitive approach to wisdom in that it emphasises knowledge-based understandings of wisdom. There is very little reference to the natural environment in any of the Berlin paradigm studies and certainly no consistent theme running through its research regarding the role of nature in either the development or application of wise judgement and/or wise behaviour. Coming out of a research background focussing on the psychology of adult development and aging, it is not surprising that the role of the natural environmental in understanding wisdom should be neglected. Psychology has traditionally undervalued the role of nature in human development and of the specific role of how we view the natural world in the creation of environmental problems (Nickerson, 2003; Stokols, 1990).

\section{Phronesis and social practice wisdom}

This school may more generally be regarded as a neo-Aristotelian research paradigm which focuses on the application of phronesis or practical wisdom in social situations to enhance the well-being of individuals and communities. Phronesis is an Aristotlean form of wisdom which is "a true and reasoned state or capacity to act with regard to the things that are good or bad for man [sic]" (Aristotle, 2009). Rooney and McKenna (McKenna, Rooney, \& Boal, 2009; McKenna, Rooney, \& Liesch, 2006; Rooney \& McKenna, 2007, 2008) have produced an important body of work on practical wisdom in the management and organisation fields. This perspective emphasises that wisdom is essentially about change for the social good. They call this "social practice wisdom", a holistic, multifaceted and discursive system "linking mind and social practice to produce well-being and human flourishing" (Rooney et al., 2010, p. 56).

In developing this holistic model these researchers looked at many different definitions and wisdom frameworks and from this work constructed their own approach. They summarise this work by describing social practice wisdom as constituted by five principles (Rooney et al., 2010, p. 57-8). Wisdom is: i) based on reason and observation; ii) inclusive of non-rational and subjective elements for making judgements; iii) directed to authentic humane and virtuous outcomes; iv) articulate, aesthetic, and intrinsically rewarding; and v) practical. Social practice wisdom is interested in the communal outcomes that wise actions result in. Of central importance here is the role wisdom plays in creating the positive conditions that enable flourishing communities. This also necessarily entails dealing with the various crises that beset organisations and societies and the role of leaders in issues such as ethical dilemmas, social and environmental impacts of business and the role of political ideologies in creating conditions that inhibit or support lasting prosperity.

There are several other researchers who have taken up the concept of phronesis and leadership. Schwartz (2011) concentrates on the role of personal "character" in wise leadership emphasising that rules and incentives take the responsibility away from people and limit their capacity to develop wisdom in their own actions and judgements. Kemmis (2012) looks at the application of phronesis in professional practice. Practical wisdom is literally the expert embodied engagement of people in their workplace with the details of their 
work. Kemmis wants to reclaim practical wisdom as not only knowledge in the heads of practitioners but also the ethical outcomes of what they do. As he says, "We not only want good professional practitioners, we want practitioners who will do good" (Kemmis, 2012, p. 12, emphasis in the original).

The practical wisdom paradigm acknowledges that the state of the earth's natural environment is an issue directly related to the study of wisdom (Rooney et al., 2010). They also know that the dualistic manner in which rational knowledge separates the human and the natural worlds is part of the story of why an integrative form of knowledge and wisdom management is needed. For example, in their critique of instrumentalist perspectives towards natural resources, Rooney et al. recognise that technocratic rationality has led to a "failure to account for and deal with environmental degradation and the unfolding catastrophe of global warming" (Rooney et al., 2010). They argue for a form of social wisdom where leaders possess "ontological acuity", that is, the ability to understand and read the knowledge systems and grounding assumptions that underlie such things as our relationship with and perspectives on natural environments and resources. But their formulation of social practice wisdom does not specifically include capacities related to the natural world.

As with the Sternberg school, there is mention of "environments" and of the "other" in McKenna and Rooney's work but these are decidedly social, organisational and work environments as opposed to natural environments. For example, in their discussion of wise leaders they quite rightly say that they "must have cognitive complexity; a capacity to deal with complex and ambiguous phenomena in complex environments" (McKenna, Rooney \& Boal, 2009, p. 185). However, the environments referred to here are the social environments that include multiple levels of human interaction and individual and collective agency. They are not natural environments. Although they regard wisdom as an essential element in the meeting of contemporary environmental challenges, there is no primary lens within the social practice wisdom framework that actually incorporates the human-nature relationship as a conceptual aspect of its theoretical system.

\section{Empirical research}

Psychometric (Ardelt, 1997, 2003; Brown \& Greene, 2006; Webster, 2007) and neurological (Meeks \& Jeste, 2009) studies have been important avenues for theorising wisdom. Ardelt's Three-Dimensional Wisdom Scale (3D-WS) defines wisdom as the integration of cognitive, reflective, and affective dimensions (Ardelt, 2003). Webster's Self-Assessed Wisdom Scale (Webster, 2007) was constructed after a review of the literature suggested five integral components of wisdom: emotional regulation; humour; critical life experiences; reminiscence and life reflection; and openness to experience. Brown's Wisdom Development Scale (WDS) involves eight dimensions: self-knowledge, emotional management, altruism; leadership, judgment; life knowledge, life skills, willingness to learn. There are strong concordances across the conceptual lenses on which these scales are based. In their review of dimensions employed in empirical research on wisdom, Meeks and Jeste (2009) found five key components: i) pro-social attitudes/behaviours, ii) pragmatic knowledge, iii) emotional regulation, iv) self-reflection, (v) tolerance of others, and (vi) tolerance for uncertainty. Again we find that these dimensions can be applied to dealing with natural environments but there is nothing in them that relates specifically to the human-nature relationship. In her review of empirical models of wisdom, Ardelt makes the point that "Most of those models ... approach wisdom from the perspective of the social sciences" (Ardelt 2004, p. 280). Social science disciplines, e.g. psychology, and fields, e.g. organisational behaviour, have dominated wisdom-related research, and input from environmental and ecological sciences has been lacking.

\section{Summary of review of ancient and contemporary}

From the foregoing overview of ancient and contemporary literature we can draw some general conclusions about how the natural environment has been theorised in wisdom research (see Table 1). We have already discussed in the review of ancient literature how conceptualisations of wisdom gradually became removed from the world of nature. This process has been continued in contemporary scientific literature where the emphasis is on psychological and sociological aspects of wisdom and the application of wise leadership to the world of contemporary organisations. Wisdom is portrayed as a form of high-functioning psychological and rational expertise in the realm of human affairs. As Kunzmann and Baltes state:

[W]isdom is inherently an intra- and interpersonal concept in that it considers problems concerning life meaning and conduct from various perspectives including the self, other people, or society at large. (Kunzmann \& Baltes, 2003, p. 334)

Nature is not a part of this picture. There are intra- and inter-personal relations but no person-nature relationship mentioned here. Environments are assumed to be psychological, interpersonal, organisational and 
cultural rather than ecological. Wise leaders solve problems and use their abilities to pursue social and organisational purposes.

Table 1: Wisdom, leadership and the human-environment relationship

\begin{tabular}{|l|l|l|l|}
\hline $\begin{array}{l}\text { Historical } \\
\text { period }\end{array}$ & Aspect of wisdom & Human-environment relation & Leadership implications \\
\hline $\begin{array}{l}\text { Early wisdom } \\
\text { writings }\end{array}$ & $\begin{array}{l}\text { Wisdom as } \\
\text { pragmatic survival }\end{array}$ & $\begin{array}{l}\text { Nature as expression of multiple } \\
\text { contending gods, human survival } \\
\text { and material existence }\end{array}$ & $\begin{array}{l}\text { Wise leaders appeased the gods } \\
\text { and nature, gave sacrifices }\end{array}$ \\
\hline $\begin{array}{l}\text { Later biblical } \\
\text { period }\end{array}$ & $\begin{array}{l}\text { Wisdom as moral } \\
\text { law }\end{array}$ & $\begin{array}{l}\text { Nature as expression of God's will, } \\
\text { as medium for communication }\end{array}$ & $\begin{array}{l}\text { Wise leaders established, } \\
\text { interpreted and upheld basic } \\
\text { codes }\end{array}$ \\
\hline $\begin{array}{l}\text { Ancient } \\
\text { Greece }\end{array}$ & $\begin{array}{l}\text { Wisdom as } \\
\text { knowledge }\end{array}$ & $\begin{array}{l}\text { Nature as dramatic background for } \\
\text { the foreground of human drama }\end{array}$ & $\begin{array}{l}\text { Wise leaders seek learning and } \\
\text { rational understanding }\end{array}$ \\
\hline $\begin{array}{l}\text { Europe } \\
\text { mystical } \\
\text { experience }\end{array}$ & $\begin{array}{l}\text { Wature as evil, to be overcome and } \\
\text { transcended } \\
\text { humanistic sense }\end{array}$ & $\begin{array}{l}\text { Wature as passive background for } \\
\text { the active foreground of human } \\
\text { drama }\end{array}$ & $\begin{array}{l}\text { Wise leaders are political leaders } \\
\text { purely with divine redemption }\end{array}$ \\
\hline $\begin{array}{l}\text { European } \\
\text { Renaissance }\end{array}$ & $\begin{array}{l}\text { Wistablish peace } \\
\text { psychological and } \\
\text { rational expertise } \\
\text { science }\end{array}$ & $\begin{array}{l}\text { Nature not present, environments } \\
\text { social and interpersonal }\end{array}$ & $\begin{array}{l}\text { Wise leaders have psychological } \\
\text { balance, use rationality to achieve } \\
\text { social/organisational goals }\end{array}$ \\
\hline Contemporary
\end{tabular}

Drawing on these various fields of contemporary research, some summary conclusions can be made regarding the metatheoretical lenses adopted by wisdom researchers (see Table 2). These lenses include selfknowledge/insight, psychological affect, cognition and behaviour, teleology (that is, the goals and outcomes to which wisdom is directed), interpersonal communication, the source of motivation, balance and boundaryspanning activity, ethics and morality, attitude towards learning and experience, leadership and decisionmaking, and aesthetic sense. In general there is a strong emphasis on conceptualising very advanced personal and psychological functioning. For example, the self-regulation of emotion and effect, the capacity for personal insight and self-knowledge and the attaining of expert knowledge in different forms are all lenses that focus on psychological qualities which characterise wisdom. Where interpersonal lenses are included, they generally talk of communicative capacities, leadership and decision-making; in other words, of how wise leaders perform in social situations. Some conceptualisations do actually conceptualise wisdom as a collective and social phenomenon. These models use lenses that focus on teleological aspects of wisdom through such goals as human flourishing, the common good, social cohesion and democratic process.

A number of issues arise from this review. Conceptualisations of wisdom: i) have become more focused on human and psycho-social qualities, ii) have become more abstracted from concerns with natural environments and our relationship to them, iii) lack capacities that refer to nature, e.g. awareness of nature, sense of physical connection, relating to animals/plants/environments, long-term sustainability or environmental empathy. At the same time, theories of wise leadership: i) emphasise human and organisational environments but not ecological ones, ii) are applied to social-cultural issues but not to the myriad problems associated with the pollution or exploitation of natural environments, and iii) are not connected to the large body of research and ideas on environmental leadership (Boiral, Cayer, \& Baron, 2009), responsible leadership (Voegtlin et al., 2012), green and sustainable management (Marcus \& Fremeth, 2009), ethical management (Brown \& Treviño, 2006) and knowledge leaderships (Waddock, 2007).

Having identified some key lenses used to conceptualise wisdom in conventional scientific research, and established the neglect of person-nature elements, we now move to review perspectives on wisdom from 
Indigenous knowledge traditions, views that are known for their emphasis on the natural world and the longterm viability of ecological systems. We seek to import lenses and concepts from this radically different perspective to provoke novel insights about wisdom and wise leadership in the context of environmental problems.

Table 2: Lenses through which wisdom has been conceptualised in contemporary science

\begin{tabular}{|l|l|}
\hline \multicolumn{1}{|c|}{ Metatheoretical lens } & \multicolumn{1}{|c|}{ Focus of lens } \\
\hline Psychological affect & Self-regulation, acceptance, patience, tolerance, humour, aesthetic sense \\
\hline Cognition & Forms of knowledge, learning, humour \\
\hline Personal behaviour & Leadership, altruistic behaviour, decision-making \\
\hline $\begin{array}{l}\text { Telos (the goal of } \\
\text { wisdom) }\end{array}$ & Human flourishing, well-being, justice, social improvement, democratic process \\
\hline Interpersonal & Communication, fairness, compassion \\
\hline Motivation & Intrinsic, compassion, justice, truth \\
\hline $\begin{array}{l}\text { Balance and boundary } \\
\text { spanning }\end{array}$ & $\begin{array}{l}\text { Mind and social practice, self and other selves, emotions and behaviour, } \\
\text { judgement and action }\end{array}$ \\
\hline Ethics and morality & Personal values, public good, honesty, compassion \\
\hline
\end{tabular}

\section{Contemporary Indigenous views}

The academic study of wisdom has largely neglected Indigenous perspectives. While Indigenous knowledge traditions are often oral and story-based, there is a substantial literature dealing with the Indigenous forms of wisdom and wise leadership (Harris \& Wasilewski, 2004; Jacobs \& Gidley, 2012; McConchie, O'Donoghue, \& Yunupingu, 2003). Across the world there are many different Indigenous peoples each with their own languages, stories and systems of knowledge. In Australia alone it is estimated that there were over 250 distinct Aboriginal languages at the time of colonisation (Walsh, 1993, p. 1). Thus, in global and even regional terms, Indigenous knowledge systems are characterised by a great diversity in language, culture and knowledge practices. A recent United Nations report on the state of the world's Indigenous peoples noted that Indigenous people occupy almost 20 per cent of the earth's land area and that, with as many as 5,000 different cultures, Indigenous societies account for the majority of the world's cultural diversity (United Nations State of the World's Indigenous Peoples, 2010).

There is not 'one' Indigenous knowledge system nor is there a set of principles that can be extracted from Indigenous wisdom systems and applied universally across different social, cultural, economic and natural environments. Jamieson observes that "each Indigenous culture offers a unique perspective, grounded as each is in a distinctive tradition, location or society" (Jamieson, 2010, p. 165).

However, this does not mean there are not underlying commonalities in thought, logic and metatheoretical perspectives between Indigenous knowledge systems (Kwaymullina \& Kwaymullina, 2010). As Indigenous scholar Leroy Little Bear observes of Indigenous systems in a North American context, "there is enough similarity among North American Indian philosophies to apply the concepts generally, even though there may be individual differences or differing emphasis" (Little Bear, 2000, p. 77). Little Bear outlines five characteristics of North American Indigenous knowledge systems as being holistic, cyclical or repetitive, generalist, processorientated, and grounded in a particular place (Little Bear, 2000, p. 78). The growing body of scholarly literature on this subject would suggest that these five characteristics also have some general applicability internationally for other Indigenous peoples (Berkes \& Berkes, 2009; Kwaymullina \& Kwaymullina, 2010). So, while this following summary is particularly informed by Australian Indigenous views, it is proposed that more general conclusions can be made on the qualities of Indigenous wisdom traditions. 
We claim that it is possible to speak generally of Indigenous systems of wisdom and sustainability provided it is understood that the application of the manifestation of these concepts is diverse, process-based and grounded in specific environments.

\section{Indigenous wisdom as relationality}

There are fundamental characteristics to the patterns of life that all Indigenous knowledge systems recognise. There is not an intellectual tradition in Indigenous systems of scepticism. Indigenous philosophies do not ask, "what is real?" or "is one thing related to another?" As Aboriginal scholar Mary Graham observes, such questions are products of intellectual traditions that divide thought from matter and subjective from objective realities (Graham, 2009, p. 76).

Indigenous knowledge systems have developed a different set of questions. The basic assumption is that everything is related and so the questions concern how forms of existence - human, animal, plant, landscape relate to each other and the ways in which these relationships move and transform (Muecke, 2011). This is often described as the concept of relationality - everything is related and the way life relates is what makes and remakes the world (Spiller et al., 2011). Indigenous systems have thus developed sophisticated frameworks for mapping the ever-shifting contexts by which relationships operate. The Maori worldview, for example, is one where "A relational, belonging worldview with the purpose of serving as a steward of resources is at the heart of Maori culture" (Spiller et al., 2011, p. 224) .

Because of this relational worldview, Indigenous wisdom is process-based (about how things relate and change) rather than structure-based (about constituent components). Relationality includes the physical environment as much as it does people, animals and plants. As Yuin Elder Max Dulumunmun Harrison observes:

It is important to read the land, to be observant of the changing colour of the leaves, and the changes in behaviour of the animals, so we become aware and recognise the messages the land is sending us (Harrison, 2009, p. 51).

In moving from reading the land to being aware of the minute details of ecosystems, Indigenous wisdom can be described as a multilevel appreciation for ecological relationships. There is intimate knowledge about the multilevel (micro-, meso-, macro- and mundo-) relationships that make up the world and, through following systems of customary law, an ability to navigate these relationships in such a way that long-term diversity and balance is sustained. This kind of complex simplicity characterises Indigenous wisdom (Knutdsen \& Suzuki, 1992).

\section{Sources of Indigenous wisdom}

Indigenous systems recognise that all life has a role to play in upholding the diversity and on-going richness of life (Knutdsen \& Suzuki, 1992). This means that each form of life must live in a way that does not prevent any other life form from overreaching its purpose. This is the wisdom of living according to Aboriginal law. Irene Watson writes:

The law is in all things, it emanates love, caring and sharing, respect for all things. That is how we kept the land in such a pristine state. The natural world was undeveloped, not because of an inability to transform the mother, the ruwe - that is the land - but because of a love and reverence for all things in the natural world (Watson, 2000, p. 4)

More recent research into the cultures of the first Australians provides strong evidence that powerful systems of management were in operation across the whole continent (Gammage, 2011). The natural environment in Australia was actually highly developed and based on management templates and landscaping mosaics that the Indigenous people created and maintained. This management process was part of their customary Law and it guided all aspects of moral and cultural life.

The sacredness of other forms of life was a central aspect of the Law. Human purposes were pursued in a context where the purpose of other animals, plants, and natural systems were respected. If this was not done, the whole would become disrupted and imbalanced. This portrays an integrated view where there is "no separation between society and individual, culture and nature, nor society and environment" (Adam \& Kneeshaw, 2008, p. 225). In their discussion of how Maori cultural values can enhance organisational performance, Spiller, Pio, Erakovic and Henare argue a "relational wisdom approach" is inherent in Maori ways of life and doing business and that this ethic can reframe economic activity and move it from a place where profit and growth comes at the expense of ecological systems to one where it enhances those systems and the 
people and communities who depend on them. They propose "a wisdom position through an ethic of kaitiakitanga or stewardship to emphasize and illustrate the interconnectedness of life in a woven universe" (Spiller et al., 2011, p. 224). For example, Indigenous peoples hunt and eat animals, but their systems do not subscribe to processes of intensively confining and farming an animal in such a manner that would prevent the animal from carrying out its purpose in the world. In this sense Indigenous wisdom is not anthropocentric but eco-centric, in that it is sourced from the relationships of life. The patterns of Indigenous logic, science, society and culture flow from the patterns of reality as seen and experienced in nature. Thus, Indigenous wisdom is not only directly connected with natural environments, as is often not the case in Western conceptualisations, it is defined by and emerges out of relationship with nature.

\section{Indigenous wisdom and natural environments}

When Indigenous people create frameworks for relationships they situate the big vision within the small vision, patterns and models must overlap and interconnect. As Indigenous scholars Deloria and Wildcat observe:

Wherever possible the larger cosmos was represented and reproduced to provide a context in which ceremonies could occur. Thus, people did not feel alone; they participated in cosmic rhythms. (Deloria \& Wildcat, 2001, p. 26)

Thus, Indigenous systems model and reproduce the whole within the specific. This allows for the kind of detailed levels of classificatory knowledge that Western science excels in, but in the Indigenous view, knowledge is always contextualised and situated within a bigger picture. Indigenous systems do not ask if it is better to be a generalist or a specialist, or if a principle is more important than an outcome. These binaries or dualities are never formulated to begin with because of a holistic vision that treats these concepts as indivisible. Modelling the whole in the part allows for a different series of questions and processes to be engaged in when attempting to make wise decisions. In other words, if the vision in which important questions are posed is reductive, then the 'answers' may not be wise, because relationships are being evaluated in isolation. A bigger vision provides a more robust framework for understanding how relationships correlate and function.

The other important aspect of the application of Indigenous wisdom is the recognition that relationships are not static but are in continual flux. Little Bear observes that of the moving nature of the world "constant motion or flux leads to a holistic and cyclical view of the world. If everything is constantly moving and changing, then one has to look at the whole to begin to see patterns" (Little Bear, 2000). Indigenous systems knowledge and experience provide a grid of knowing held in the mind as a map; that finds its source in the world, but is not imposed on the world in an absolute sense because it allows for a constantly updating picture of the shifting contexts of relationships. When Indigenous systems model the whole in the part they create a responsive framework built on shifting relationships. This might superficially appear to create uncertainty, in that it is not a model that is defined and absolute, but it is an approach that is highly responsive and adaptive to change. Indigenous systems operate on a long observed understanding that there is an inherent predictability in the fundamental nature of relationships. A relationship that is prevented from relating is unhealthy and an unhealthy relationship will always lead to an unwise outcome - if not in the short term, then certainly further down the line. Thus, modelling the part in the whole is both a responsive and predictive approach to acting in wise ways in the world.

The importance of Indigenous wisdom to the maintenance of biodiversity has been recognised for some time, and led renowned geographer Bernard Nietschmann to posit his "rule of Indigenous environments" (Nietschmann, 1992, p. 3), that where there are Indigenous peoples with a homeland then there will be rich and flourishing ecologies and biological environments. A recent United Nations report on the State of the World's Indigenous Peoples noted that Indigenous peoples inhabit areas that have high biological diversity indicating that human occupation and settlement are not incompatible with ecological diversity (United Nations State of the World's Indigenous peoples, 2010).

It is no accident that Indigenous cultures have created and sustainably managed rich, natural ecosystems. Indigenous societies used powerful technologies to shape and manage their environs, much as modern industrial societies do, but the outcome of that management was on-going natural diversity. Bill Gammage has provided immense detail on how this was done in his book, The Biggest Estate: How Aborigines created Australia (2011). For the Indigenous peoples of Australia, the interweaving of legal, spiritual, religious and cultural life created an ethical imperative to care for, maintain and revere their "country". 
The concept of country is a crucial one in aboriginal culture. Country is a living and diverse concept that can mean "a nourishing terrain" (Rose, 1996), a particular place, a general concept for the sacred and a specific custodial relationship between a person, tribe or community to their lands (Graham, 1999). Abundance in cultural, economic, and biological life flowed out of this ethic of caring for country. Gammage (2011, p. 138) says that:

A rich and time-eating spiritual life builds on abundance, not poverty. In the driest and most fireprone continent on earth, abundance was not natural. It was made by skilled, detailed and provident management of country.

In Indigenous knowledge traditions the whole of the socio-cultural system is shaped around reciprocal relationships with local natural environments. This includes systems of governance and leadership, economy, exchange and trade, language, social, religions and cultural practices and more broadly Indigenous life worlds and worldviews.

\section{Summary of review of Indigenous wisdom traditions}

Table 3 provides a summary of metatheoretical lenses that can be used to characterise wisdom and wise leadership in Indigenous knowledge systems. Perhaps the most important of these is relationality, the principle that connects and inter-relates the different spheres of Indigenous life. Each thing has a relationship with each other thing and with the totality of all things. Hence relationships are not only multidimensional but also multilevel in that the micro-world of personal experience has direct implications for macro-worlds of community and "country".

Table 3: Lenses through which wisdom has been conceptualised in Indigenous traditions

\begin{tabular}{|c|c|}
\hline Metatheoretical Lens & Focus of Lens \\
\hline $\begin{array}{l}\text { Radical relationality and } \\
\text { process }\end{array}$ & $\begin{array}{l}\text { Interpersonal and social relations, environmental relations, metaphysical } \\
\text { relations, relationships are multilevel and multidimensional, navigating the } \\
\text { process complexities that arise from relationality }\end{array}$ \\
\hline $\begin{array}{l}\text { Ethics of integrated } \\
\text { sacredness }\end{array}$ & Respect, sacredness of natural world, custodial ethic of caring for "country" \\
\hline Balance & $\begin{array}{l}\text { Preservation and flourishing of all life systems (human, animal, plant, } \\
\text { environmental, etc) }\end{array}$ \\
\hline $\begin{array}{l}\text { Multilevel ecology (Holism } \\
\text { and interconnectivity) }\end{array}$ & $\begin{array}{l}\text { Intuitive experience and cultural assumption of the connectedness between, } \\
\text { and mutual co-creation of, human and environmental systems }\end{array}$ \\
\hline $\begin{array}{l}\text { Intergenerational } \\
\text { temporality }\end{array}$ & The time dimension, intergenerational, long-term, cyclical, process-related \\
\hline $\begin{array}{l}\text { Elders and heritage (wise } \\
\text { leadership) }\end{array}$ & Embodied heritage, holders of story, knowledge and history \\
\hline
\end{tabular}

Indigenous views on wisdom are specifically related to the personal in the respect given to wise elders in the community. However, rather than seeing elders as just possessing wise qualities, it is more that they are holders of heritage and history through their transmission of story and embodied knowledge. Harrison has spoken about indigenous elders' sense of responsibility in communicating their knowledge. In the book Elders: Wisdom from Australia's Indigenous Leaders, Harrison says of his own sense of leadership:

I'm here to teach people let's be reconciled with the Mother, with Mother Earth. If we can reconcile with the Mother, then we can breathe the air and walk together in harmony. Every part of this land is sacred; this teaching is the most important part of our survival. It is our home, we live here together. This is reconciliation, to look each other in the eye and know this equally. (Harrison, 2003, p. 2)

While the shifting contexts in which wisdom might be lived are diverse and complex, those that act in ways 
that balance and sustain healthy natural and human relationships are wise leaders and those that do not are foolish. The moral implications of wise and unwise leadership are central to most Indigenous creation stories (Greene, Tramacchi, \& Gill, 1992, p. 5). Thus, many statements of Indigenous wisdom such as 'we are all related', 'respect the land' and 'never take more than you need' are simple, direct moral instructions from which complex social, economic, cultural and environmental processes unfold.

Indigenous perspectives on wisdom emphasise the connectedness and the interpenetration of time, space and relationship. This holds particularly true for the lens of time which not only takes a longer term view of the implications of actions on future generations but sees the welfare of the future and the honouring of the past as a present responsibility.

\section{METATHEORETICAL REFLECTIONS ON BIG PICTURE WISDOM}

If we compare the meta-theoretical overviews of conventional and Indigenous perspectives on wisdom we can find several commonalities but also some important differences. There is agreement in the view that wisdom is something that both connects and crosses different boundaries. While the conventional scientific emphasis is on finding connections across personal boundaries so that personal integrity is highlighted, in Indigenous understandings boundary crossing occurs much more in terms of social and broader environmental connections. It could be said that where scientific views emphasise personal integrity, Indigenous views emphasise bio-social integrity, that is, a wisdom that connects people and natural environments across ecological and temporal boundaries. This is not simply a contrast between individual versus collective perspectives. The indigenous perspective assumes complete interdependence across social and ecological environments. The second area of shared focus is that wisdom can be found in the personhood of wise individuals and particularly in their capacity to lead, display and pass on knowledge and to give wise counsel. Once again, however, there is a difference in how this lens is treated. Where the scientific perspective emphasises psychological dimensions such as emotional regulation, tolerance and cognitive expertise, the Indigenous expression of this lens sees wise individuals as transmitters of socio-cultural heritage. They embody not just a life-time of personal experience but generations of cultural experience.

One important difference that is evident from these meta-theoretical summaries is that where conventional scientific understandings focus on the human world of personal and social wisdom, Indigenous worldviews speak of wisdom within a much more connected matrix of the human, the natural, the historical, the environmental and the communal. To be a wise leader cannot be separated from participating in the relational life of one's "country". This relationality lens plays out most particularly in Indigenous attitudes towards place and the natural world where a concept of "sacred geography" and "sacred sites" (Basso, 1996 ) lies at the heart of what it means to be wise. We have called this the "sacred ecology lens" because it involves a sense of spiritual connectedness that includes and balances multiple human and biological systems.

A second important point of differentiation between conventional and Indigenous understandings lies in the timeframe in which wisdom is contextualised. Although there is some reference to long-term perspective taking and future-orientated decision-making, in the scientific study of wisdom these elements are not regarded as core "metaheuristics" (Baltes \& Staudinger, 2000) of what it means to be wise. In contrast, Indigenous views assume the intergenerational, the long-term as a framing for any discussion of what wisdom might mean. Intergenerational factors are inherent to wise processes and decisions. Furthermore the interconnectedness of relations cannot be separated from this inclusive time lens. As Dumont puts it:

Our present day [Indigenous] thinking is inclusive of the legacy of our ancestors and of what our ancestors are waiting for us to do. Our thoughts also include the future generations, recognizing that they are already looking back toward us with the awareness that our decisions and our actions are impacting them. It is a living past, a living future, and we are the living connection in between. Indigenous intelligence is active on all these levels. (Dumont, 2005, para. 5)

\section{CONCLUSION}

In this paper we have carried out a metatheoretical review of ancient, scientific and Indigenous perspectives on wisdom and its relationship to the natural environment. We have blended ideas from diverse cultural and theoretical domains to provide a source for theory-building in the fields of wise leadership and its application to environmental management. This has been an exercise in what Oswick and his colleagues call "anomalous reasoning", an approach to theory-building which "compares disparate and unrelated domains on the basis of 
similarities" (Oswick et al., 2011, p. 333). Anomalous reasoning is an abstract form of ideas blending and involves identifying resemblances and connections across diverse domains to produce new insights.

Including both conventional and Indigenous lenses opens the possibility of an expanded form of "big picture" wisdom that can be applied to global sustainability challenges. The special place given to relationality, multilevel interconnectivity, temporality, ecological sacredness and wise leadership in Indigenous perspectives offers particularly exciting possibilities in this regard. Conventional scientific understandings of wisdom do not possess these perspectives. From this point of view, Indigenous perspectives on wisdom offer some important contributions that may be vital for addressing current global challenges, particularly those of an environmental or sustainability nature.

These Indigenous lenses also alert us to perspectives on wisdom that, while currently not present in the scientific literature on wisdom and wise leadership, may be found in other scientific domains. For example, in comparing scientific and Indigenous perspectives on wisdom it's apparent that scientific theories have neglected the lenses of temporality, relationality and spirituality, particularly as regards human relationships with the natural world. However, these lenses are present in some theories coming from sustainability research. One of the most commonly used definitions of sustainability specifically includes the lens of intergenerational timeframes (World Commission On Environment and Development, 1987). Similarly, multilevel interconnectivity has been a common lens used to view human and natural environment relations. For example, Starik and Rands' development of a multilevel/multisystem web of relationships describes a model in which the "relationships between the organization and entities at the individual, organizational, political-economic, social-cultural, and ecological environment levels are examined" (Starik \& Rands, 1995, p. 908). This model basically says that different levels/systems are embedded in each other in a way that any of them represents a whole by its own but at the same time is a part of the system at the higher level. There are very strong connections here with Indigenous views on wisdom.

To respond adequately to the environmental challenges that now confront organisations, wise leaders and wise communities of leaders will be needed who collectively possess the qualities described by conventional perspectives on wisdom. Such leaders and leadership groups will have emotional maturity, respect for pluralism, expert knowledge in relevant fields, be able to take action that inspires confidence and engaged followership in themselves and others, and have strong personal morality and ethical commitments that are based on core values and cross-cultural norms of conduct. These elements will be balanced with practical and strategic capacities for enacting decisions and creating concrete change. However this matrix of abilities will require additional capacities to develop decisions and action that address the global scale of complex environmental challenges. Wise leaders and leadership will also need to develop an intergenerational perspective on the temporal aspects of decisions and their implications, will ground their strategies and plans on an assumption that social and ecological systems are radically interdependent, and they will also need to derive their ethical responsibilities from a deep sense of the sacred connectedness of the human and the natural.

A number of implications emerge from this discussion for the development of wisdom research. First, the unique lenses used in Indigenous knowledge traditions need to be incorporated more systematically into current research. Second, that process cannot occur without a deeper general engagement with Indigenous cultures. Third, wisdom research has tended to neglect the relationship between wisdom and global crisis and how wisdom might contribute to meeting these challenges. Fourth, we have seen that scientific disciplines and fields such as sustainability, deep ecology and environmental science share with Indigenous sciences a number of core meta-theoretical lenses that can contribute to a more globally engaged understanding of wisdom. A greater engagement with these ideas has much to contribute to understanding wisdom and its practical application to the challenges of contemporary times.

Over a decade ago, a number of leading researchers published an important statement on the rise of sustainability science (Kates et al., 2001). The statement concluded with the authors posing ten core research questions on meeting "fundamental human needs while preserving the life-support systems of planet Earth" (Kates et al., 2001, p. 641). The first question they posed was this:

How can the dynamic interactions between nature and society ... be better incorporated into emerging models and conceptualizations that integrate the Earth system, human development, and sustainability? (Kates et al., 2001)

Indigenous worldviews represent a deep and relatively untapped resource for addressing this crucial question. 
Indigenous worldviews offer a unique source of wisdom for making sense of the relationship between nature and society. The scientific study of wisdom and wise leadership has much to gain from engaging with Indigenous lenses of intergenerationality, radical relationality, multi-level ecology and integrated sacredness. Reflecting on the deep connections and potential learning that might occur between contemporary and indigenous wisdom traditions, Kxao Moses fOma and Axel Thoma point out that:

Our wisdom traditions and scientific practices are rooted in Indigenous ways of seeing the world that have been around for scores of millennia and in fact have functioned to preserve precious resources of Mother Earth and the natural world, and must be valued and not exploited. (fOma \& Thoma, 2006, p. 18)

A big picture understanding of wisdom that integrates indigenous and scientific perspectives on wisdom and wise leadership will be crucial in building a global, intergenerational capacity for sustaining human and biological systems.

\section{AUTHOR DETAILS}

Assist. Prof. Mark Edwards (All correspondence): Business School, The University of Western Australia, 35 Stirling Highway, Crawley, WA 6009, Australia. Phone: + 6186488 5869, E-mail: mark.edwards@uwa.edu.au,

Assoc. Prof. Roberto Biloslavo: Faculty of Management Koper, University of Primorska, Slovenia Phone: +386 5 61020 00, E-mail: roberto.biloslavo@fm-kp.si

Dr. Blaze Kwaymullina: Terra Rosa, Cultural Resource Management, Phone: + 6180400132744 , E-mail: blaze.kwaymullina@terrarosacrm.com

Assist. Prof. Ambelin Kwaymullina: Law School, University of Western Australia, Phone: + 6186488 2907, Email: ambelin.kwaymullina@uwa.edu.au

\section{REFERENCES}

fOma, K. M., \& Thoma, A. (2006), Indigenous san knowledge and survival struggles. In J. E. Kunnie \& N. I. Goduka (Eds.), Indigenous peoples' wisdom and power: Affirming our knowledge through narratives (pp. 3-18). Aldershot, UK: Ashgate publishing.

Adam, M. C., \& Kneeshaw, D. (2008), Local level criteria and indicator frameworks: A tool used to assess aboriginal forest ecosystem values. Forest Ecology and Management, 255(7), 2024-2037.

http://dx.doi.org/10.1016/j.foreco.2007.12.051

Ardelt, M. (1997), Wisdom and life satisfaction in old age. The journals of gerontology. Series B, Psychological sciences and social sciences, 52(1), P15-27. http://dx.doi.org/10.1093/geronb/52B.1.P15

Ardelt, M. (2003), Empirical assessment of a three-dimensional wisdom scale. Research on Aging, 25(3), 275324. http://dx.doi.org/10.1177/0164027503025003004

Ardelt, M. (2004), Wisdom as expert knowledge system: A critical review of a contemporary operationalization of an ancient concept. Human Development, 47(5), 257-285. http://dx.doi.org/10.1159/000079154

Aristotle. (2009), The nichomachian ethics, book vi, chapter $v$.

http://nothingistic.org/library/aristotle/nicomachean/index.html: Stephen R. Mclntyre, Nothingistic.

Avolio, B. J., Walumbwa, F. O., \& Joseph, J. M. (2006), Authentic leadership: Moving hr leaders to a higher level Research in personnel and human resources management (pp. 273-304). Greenwich, CT: JAI.

http://dx.doi.org/10.1016/S0742-7301(06)25007-2

Baltes, P. B., Glück, J., \& Kunzmann, U. (2002), Wisdom: Its structure and function in regulating successful lifespan development. In C. R. Snyder \& S. J. Lopez (Eds.), Handbook of positive psychology (pp. 327-347). New York: Oxford University Press.

Baltes, P. B., \& Staudinger, U. M. (2000), Wisdom: A metaheuristic (pragmatic) to orchestrate mind and virtue toward excellence. American Psychologist, 55(1), 122-136. http://dx.doi.org/10.1037//0003-066X.55.1.122

Basso, K. H. (1996), Wisdom sits in places: Landscape and language among the western apache. Albuquerque: 
University of New Mexico Press.

Beaulieu, P. A. (2007), The social and intellectual setting of babylonian wisdom literature. In R. J. Clifford (Ed.), Wisdom literature in mesopotamia and israel (pp. 3-20). Atlanta: Society of Biblical Literature.

Berkes, F., \& Berkes, M. K. (2009), Ecological complexity, fuzzy logic, and holism in indigenous knowledge. Futures, 41(1), 6-12. http://dx.doi.org/10.1016/j.futures.2008.07.003

Birren, J. E., \& Svensson, C. (1990), Wisdom in history. In R. J. Sternberg \& J. Jordan (Eds.), A handbook of wisdom: Psychological perspectives (pp. 1-31). Cambridge: Cambridge University Press.

Boal, K. B. (2000), Strategic leadership research: Moving on. [Article]. Leadership Quarterly, 11(4), 515. http://dx.doi.org/10.1016/S1048-9843(00)00057-6

Boiral, O., Cayer, M., \& Baron, C. M. (2009), The action logics of environmental leadership: A developmental perspective. Journal of Business Ethics, 85(4), 479-499. http://dx.doi.org/10.1007/s10551-008-9784-2

Brown, M. E., \& Treviño, L. K. (2006), Ethical leadership: A review and future directions. The Leadership Quarterly, 17(6), 595-616. http://dx.doi.org/10.1016/j.leaqua.2006.10.004

Brown, S. C., \& Greene, J. A. (2006), The wisdom development scale: Translating the conceptual to the concrete. Journal of College Student Development, 47(1), 1-19. http://dx.doi.org/10.1353/csd.2006.0002

De Vries, M. F. R. K., \& Flornet-Traecy, E. (2002), Global leadership from a to z: Creating high commitment organizations. Organizational Dynamics, 30(4), 295-309. http://dx.doi.org/10.1016/S0090-2616(02)00067-0

Deloria, V., \& Wildcat, D. ( 2001), Power and place: Indian education in America. Golden, COL: Fulcrum Resources.

Denis, J.-L., Lamothe, L., \& Langley, A. (2001), The dynamics of collective leadership and strategic change in pluralistic organizations. [Article]. Academy of Management Journal, 44(4), 809-837. http://dx.doi.org/10.2307/3069417

Dumont, J. (2005), First nations regional longitudinal study(rhs): Cultural framework Retrieved June 1, 2012, 2012, from http://www.rhs-ers.ca/

Feiss, H. (2000), Essential monastic wisdom: Writings on the contemplative life. New York: HarperOne.

Gammage, B. (2011), The biggest estate on earth: How aboriginals made australia. Sydney: Allen \& Unwin.

Graen, G. B., \& Uhl-Bien, M. (1995), Relationship-based approach to leadership: Development of leadermember exchange $(\operatorname{Imx})$ theory of leadership over 25 years: Applying a multi-level multi-domain perspective. The Leadership Quarterly, 6(2), 219-247. http://dx.doi.org/10.1016/1048-9843(95)90036-5

Graham, M. (1999), Some thoughts about the philosophical underpinnings of aboriginal worldviews. [Article]. Worldviews: Environment Culture Religion, 3(2), 105-118. http://dx.doi.org/10.1163/156853599x00090

Graham, M. (2009), Understanding agency in terms of place: A proposed aboriginal research methodology. Philosophy Activism Nature, 6, 71-78.

Greene, G., Tramacchi, J., \& Gill, L. (1992), Tjarnary roughtail. Broome, Australia: Magabala Books.

Gup, B. E. (2010), The financial and economic crises: An international perspective. Cheltenham: Edward Elgar.

Hajkowicz, S. A., Cook, H., \& Littleboy, A. (2012), Our future world: Global megatrends that will change the way we live - the 2012 revision. Melbourne, Australia.: Commonwealth Scientific and Industrial Research Organisation (CSIRO).

Hall, S. S. (2010), Wisdom: From philosophy to neuroscience. Brisbane: University of Queensland Press.

Harris, L., \& Wasilewski, J. (2004), Indigenous wisdom of the people forum: Strategies for expanding a web of transnational indigenous interactions. Systems Research and Behavioral Science, 21(5), 505-505.

http://dx.doi.org/10.1002/sres.632

Harrison, M. (2009), My people's dreaming. Warriewood NSW: Finch Publishing.

Harrison, M. D. (2003), Healing. In L. O'Donoghue, M. Yunupingu \& P. McConchie (Eds.), Elders: Wisdom from Australia's indigenous leaders (pp. 1-8). Melbourne: Cambridge University Press. 
Hernandez, M., Eberly, M. B., Avolio, B. J., \& Johnson, M. D. (2011), The loci and mechanisms of leadership: Exploring a more comprehensive view of leadership theory. The Leadership Quarterly, 22(6), 1165-1185. http://dx.doi.org/10.1016/j.leaqua.2011.09.009

Jacobs, A., \& Gidley, M. (2012), Native american wisdom: A spiritual tradition at one with nature. London: Watkins.

Jamieson, J. (2010), The role of indigenous communities in the pursuit of sustainability. New Zealand Journal of Environmental Law, 14, 161-196.

Jones, R. (1969), Fire-stick farming. Australian Natural History, 16(224-8).

Kates, R. W., Clark, W. C., Corell, R., Hall, J. M., Jaeger, C. C., Lowe, I., . . Mooney, H. (2001), Sustainability science. Science, 292(5517), 641. http://dx.doi.org/10.1126/science.1059386

Kemmis, S. (2012), Phronēsis, experience and the primacy of praxis. In A. Pitma \& A. Kinsella (Eds.), Phronēsis as professional knowledge: Practical wisdom in the professions (pp. 147-162). Rotterdam: Sense.

Knutdsen, P., \& Suzuki, D. (1992), Wisdom of the elders. St Leonards: Australia: Allen \& Unwin.

Kunzmann, U., \& Baltes, P., B. (2003), Wisdom-related knowledge: Affective, motivational, and interpersonal correlates. Personality and Social Psychology Bulletin, 29(9), 1104-1119.

http://dx.doi.org/10.1177/0146167203254506

Kwaymullina, B., \& Kwaymullina, A. (2010), Learning to read the signs: Law in an indigenous reality. Journal of Australian Studies, 34(2), 195-208. http://dx.doi.org/10.1080/14443051003721189

Little Bear, L. (2000), Jagged worldviews colliding. In B. Marie (Ed.), Reclaiming indigenous voice and vision (pp. 77-85). Vancouver, BC: UBC Press.

Lynham, S. A. (2000), Theory building in the human resource development profession. Human Resource Development Quarterly, 11(2), 159-178. http://dx.doi.org/10.1002/1532-1096(200022)11:2\%3C159::AIDHRDQ5\%3E3.0.CO;2-E

Maak, T., \& Pless, N. M. (2006), Responsible leadership in a stakeholder society: A relational perspective. Journal of Business Ethics 66(1), 99-115. http://dx.doi.org/10.1007/s10551-006-9047-z

Marcus, A. A., \& Fremeth, A. R. (2009), Green management matters regardless. [Article]. Academy of Management Perspectives, 23(3), 17-26.

McConchie, P., O'Donoghue, L., \& Yunupingu, M. (2003), Elders: Wisdom from australia's indigenous leaders. Melbourne: Cambridge University Press.

McKenna, B., Rooney, D., \& Boal, K. B. (2009), Wisdom principles as a meta-theoretical basis for evaluating leadership. The Leadership Quarterly, 20(2), 177-190. http://dx.doi.org/10.1016/j.leaqua.2009.01.013

McKenna, B., Rooney, D., \& Liesch, P. (2006), Beyond knowledge to wisdom in international business strategy. Prometheus, 24(3), 283-300. http://dx.doi.org/10.1080/08109020600877576

Meeks, T. W., \& Jeste, D. V. (2009), Neurobiology of wisdom: A literature overview. Archives General Psychiatry, 66(4), 355-365. http://dx.doi.org/10.1001/archgenpsychiatry.2009.8

Muecke, S. (2011), Australian indigenous philosophy. CLCWeb: Comparative Literature and Culture, 13(2), 2-7. http://dx.doi.org/10.7771/1481-4374.1741

Nickerson, R. S. (2003), Psychology and environmental change. New Jersey: Erlbaum

Nietschmann, B. Q. (1992), The interdependence of biological and cultural diversity: Occasional paper \#21. Olympia, WA: Center for World Indigenous Studies.

O’Brien, K. (2012), Global environmental change ii: From adaptation to deliberate transformation. [Article]. Progress in Human Geography, 36(5), 667-676. http://dx.doi.org/10.1177/0309132511425767

Oswick, C., Fleming, P., \& Hanlon, G. (2011), From borrowing to blending: Rethinging the process of organizational theory building. [Article]. Academy of Management Review, 36(2), 318-337. http://dx.doi.org/10.5465/AMR.2011.59330932

Pasupathi, M., Staudinger, U. M., \& Baltes, P. B. (2001), Seeds of wisdom: Adolescents' knowledge and 
judgement about difficult life problems. Developmental Psychology, 37, 351-361.

http://dx.doi.org/10.1037/0012-1649.37.3.351

Penchansky, D. (2012), Understanding wisdom literature: Conflict and dissonance in the hebrew text. Grand Rapids, MI: Wm. B. Eerdmans Publishing Company.

Perdue, L. G. (2007), Wisdom literature: A theological history. Louisville, Kentucky: Westminster John Knox Press.

Portugal, E., \& Yukl, G. (1994), Perspectives on environmental leadership. The Leadership Quarterly, 5(3-4), 271-276. http://dx.doi.org/10.1016/1048-9843(94)90017-5

Robinson, D. N. (1990), Wisdom through the ages. In R. J. Sternberg (Ed.), Wisdom: Its nature, origins, and development (pp. 13-24). Cambridge: Cambridge University press.

Rooney, D., \& McKenna, B. (2007), Wisdom in organizations: Whence and whither. Social Epistemology, 21(2), 113-138.

Rooney, D., \& McKenna, B. (2008), Wisdom in public administration: Looking for a sociology of wise practice. Public Administration Review(July/August), 709-721. http://dx.doi.org/10.1080/02691720701393434

Rooney, D., McKenna, B., \& Liesch, P. (2010), Wisdom and management in the knowledge economy. New York: Routledge.

Rose, D. B. (1996), Nourishing terrains: Australian aboriginal vies of landscape and wilderness. Canberra: Australian Heritage Commission.

Schwartz, B. (2011), Practical wisdom and organizations. In B. M. Staw \& A. P. Brief (Eds.), Research in organizational behavior: An annual series of analytical essays and critical reviews (Vol. 31, pp. 3-23).

Spiller, C., Pio, E., Erakovic, L., \& Henare, M. (2011), Wise up: Creating organizational wisdom through an ethic of kaitiakitanga. Journal of Business Ethics, 104(2), 223-235. http://dx.doi.org/10.1007/s10551-011-0905-y

Starik, M., \& Rands, G. P. (1995), Weaving an integrated web: Multilevel and multisystem perspectives of ecologically sustainable organizations. Academy of Management Review, 20(4), 908-935.

http://dx.doi.org/10.2307/258960

Staudinger, U. M., \& Pasupathi, M. (2003), Correlates of wisdom-related performance in adolescence and adulthood: Age-graded differences in "paths" toward desirable development. Journal of Research on Adolescence, 13(3), 239-268. http://dx.doi.org/10.1111/1532-7795.1303001

Sternberg, R. J. (1998), A balance theory of wisdom. Review of General Psychology, 2(4), 347-365. http://dx.doi.org/10.1037//1089-2680.2.4.347

Sternberg, R. J. (2003), Wisdom, intelligence and creativity synthesized. Cambridge, UK: Cambridge University Press.

Sternberg, R. J., \& Jordan, J. (Eds.), (2005). A handbook of wisdom: Psychological perspectives. New York: Cambridge University Press.

Stokols, D. (1990), Instrumental and spiritual views of people-environment relations. American Psychologist, 45(5), 641-646. http://dx.doi.org/10.1037//0003-066X.45.5.641

Tapio, P., \& Willamo, R. (2008), Developing interdisciplinary environmental frameworks. Ambio, 37(2), 125133. http://dx.doi.org/10.1579/0044-7447(2008)37\%5B125:DIEF\%5D2.0.CO;2

Taylor, L. (2005), The power of knowledge: The resonance of tradition. Canberra, ACT: Aboriginal Studies Press.

Taylor, S. R. (1992), Green management: The next competitive weapon. Futures, 24(7), 669-680.

http://dx.doi.org/10.1016/0016-3287(92)90075-Q

Thompson, L. (2010), The global moral compass for business leaders. Journal of Business Ethics, 93, 15. http://dx.doi.org/10.1007/s10551-010-0624-9

Torraco, R. J. (2005), Writing integrative literature reviews: Guidelines and examples. Human Resource Development Review, 4(3), 356-367. http://dx.doi.org/10.1177/1534484305278283

Tubbs, S. L., \& Schulz, E. (2006), Exploring a taxonomy of global leadership competencies and meta- 
competencies. Journal of American Academy of Business, Cambridge, 8(2), 29-34.

United Nations. (2010), State of the World's Indigenous Peoples. Department of Economic and Social Affiars. New York: United Nations.

Voegtlin, C., Patzer, M., \& Scherer, A. G. (2012), Responsible leadership in global business: A new approach to leadership and its multi-level outcomes. Journal of Business Ethics, 105(1), 1-16.

http://dx.doi.org/10.1007/s10551-011-0952-4

Waddock, S. (2007), Leadership integrity in a fractured knowledge world. Academy of Management Learning \& Education, 6(4), 543-557. http://dx.doi.org/10.5465/AMLE.2007.27694954

Walsh, M. (1993), 'Languages and their status in aboriginal australia. In M. Walsh \& C. Yallop (Eds.), Language and culture in aboriginal australia (Vol. 1 - 13). Canberra: Aboriginal Studies Press.

Waltke, B. K. (1979), The book of proverbs and ancient wisdom literature. Bibliotheca Sacra, 136(3), 211-238.

Watson, I. (2000), Kaldowinyeri - munaintya in the beginning,. Flinders Journal of Law Reform, 4(1), 3-19.

Webster, J. D. (2007), Measuring the character strength of wisdom. International Journal of Aging and Human Development, 65, 163-183. http://dx.doi.org/10.2190/AG.65.2.d

WEF. (2012). Global risks 2012. Geneva: World Economic Forum.

Whittemore, R., \& Knafl, K. (2005), The integrative review: Updated methodology. [Article]. Journal of Advanced Nursing, 52(5), 546-553. http://dx.doi.org/10.1111/j.1365-2648.2005.03621.x

World Commission On Environment and Development. (1987), Report of the world commission on environment and development: Our common future Oxford: Oxford Press.

World Economic Forum. (2013). Global risks 2013. In L. Howell (ed.) (Ed.). Geneva: WEF.

WWF. (2012). Living planet report. London: World Wide Fund For Nature.

Yammarino, F. J., Dionne, S. D., Schriesheim, C. A., \& Dansereau, F. (2008), Authentic leadership and positive organizational behavior: A meso, multi-level perspective. The Leadership Quarterly, 19(6), 693-707. http://dx.doi.org/10.1016/j.leaqua.2008.09.004

Yang, S. (2011), Wisdom displayed through leadership: Exploring leadership-related wisdom. The Leadership Quarterly, 22(4), 616-632. http://dx.doi.org/10.1016/j.leaqua.2011.05.004

Zhang, X., Fu, P., Xi, Y., Li, L., Xu, L., Cao, C., . . Ge, J. (2012), Understanding indigenous leadership research: Explication and Chinese examples. The Leadership Quarterly, 23(6), 1063-1079.

http://dx.doi.org/10.1016/j.leaqua.2012.10.009 